\title{
KELOMPOK PENYELENGGARA PEMUNGUTAN SUARA (KPPS) PEMILU 2019: TANGGUNGJAWAB DAN BEBAN KERJA
}

\author{
Andreas Pandiangan \\ Program Studi Ilmu Komunikasi, UNIKA Soegijapranata, Semarang, Indonesia \\ Email: pandiangan@unika.ac.id
}

\begin{abstract}
Abstrak
Kelompok Penyelenggara Pemungutan Suara (KPPS) merupakan ujung tombak pelaksanaan pemungutan dan penghitungan suara di Pemilu 2019.Termasuk melayani hak pilih masyarakatdan peserta pemilu.Penelitian ini bertujuan menjelaskan tanggung jawab dan beban KPPS diPemilu 2019 setelah memaparkan perjalanan KPPS selama ini. Dalam kerangka kajian kebijakan kualitatif, penelitian ini akan menganalisa regulasi badan penyelenggara pemilu serta tanggungjawab dan bebas tugas KPPS. Penelitian ini menemukan bahwa hasil kerja KPPS akan sangat menentukan kualitas Pemilu 2019 dan berpeluang akan digugat masyarakat dan peserta Pemilu 2019 bila penyelenggaraan pemilu tidak memenuhi prinsip-prinsip: mandiri, jujur, adil, berkepastian hukum, tertib, terbuka, proporsional, profesional, akuntabel, efektif dan efisien.Tugas, wewenang dan kewajiban KKPS yang demikian luas dan berat di Pemilu 2019 kiranya diimbangi dengan perubahan organisasi dan fasilitas serta kesejahteraan yang diterima oleh Ketua dan Anggota Kelompok Penyelenggara Pemungatan Suara (KPPS).
\end{abstract}

Kata kunci: Kelompok penyelenggara pemungutan suara, pemilu 2019, tugas dan wewenang

\begin{abstract}
The Voting Organizing Group (KPPS) is the spearhead of voting and counting in the 2019 Election. This includes serving the voting rights of the community an election partisicipants.This study aims to explain the responsibilities and burdens of KPPS in the 2019 Election after describing the KPPS journey so far. Within the framework of qualitative policy studies, this study will analyze the regulations of the EMB as well as the responsibilities and duties of KPPS. This study found that the work of KPPS will greatly determine the quality of the 2019 Election and have the opportunity to be sued by the public and participants of the 2019 Election if the implementation of elections does not fulfill the principles: independent, honest, fair, legal certainty, orderly, open, proportional, professional, accountable, effective and efficient. The tasks, authorities anf obligations of such a wide and severe KPPS in the 2019 Election would be offset by changes in organization and facilities and welfare received by the Chair anf Members of the Voting Organizing Group (KPPS).
\end{abstract}

Keywords: Voting organizers group, 2019 elections, duties and authorities

Submited: 07-02-2019; Accepted: 29-04-2019; Published: 30-04-2019

*Korespondensi: Program Studi Ilmu Komunikasi, UNIKA Soegijapranata Semarang

Jl. Pawiyatan Luhur Sel. IV No. 1, Bendan Duwur, Banyumanik, Kota Semarang, Jawa

Tengah 50234

Email: pandiangan@unika.ac.id 


\section{PENDAHULUAN}

Kajian, wacana dan evaluasi (Hamimah 2018) atas kinerja penyelenggara pemilihan umum (pemilu) selama ini cenderung hanya pada lembaga di tingkat nasional dan atau provinsi/kabupaten-kota (Pratama 2016). Salah satunya studi Ramlan Surbakti dan Kris Nugroho di tahun 2015 (Ramlan Surbakti 2015). Termasuk terbaru di tahun 2016 lalu yang dilakukan ICW-Perludem Hasil Survey Evaluasi Kinerja KPU dan Bawaslu.Sehingga dapat dipastikan solusi yang ditawarkan lebih pada jalan keluar persoalan yang dihadapi badan penyelenggara yang tetap sifatnya. Termasuk harapan yang dialamatkan ke badan penyelenggara tersebut guna peningkatan kinerjanya (Handitya 2018). Adanya hal yang demikian tentunya hanya berdampak pada usaha untuk melakukan perkembangan dan perbaikan di tingkat KPU dan Bawaslu. KPU atau Komisi Pemilihan Umum setiap periodenya selalu mencoba menyesuaikan guna menciptakan pemilu yang berintegritas baik (Agus 2018; Ola 2017). Memang tidak bisa dipungkiri bahwa KPU memiliki peran penting, salah satunya adalah sebagai agen sosialisasi guna mensukseskan pemilu sehingga partisipasi masyarakat dalam memilih terus meningkat.KPU juga menjadi Koordinator dalam pemilu dengan bagian-bagian dibawahnya.Pentingnya peran KPU ini tentunya juga berimplikasi pada banyaknya survey tentang kinerja KPU guna perbaikan terus-menerus, hal ini dikarenakan KPU menjadi kepala dari bagian-bagian dari panitia penyelenggara Pemilu.

Bukan hanya KPU yang terus menerus melakukan perbaikan, Bawaslu atau Badan Pengawas Pemilu pun demikian (Fauzi 2018; Haryanti 2015). Hal ini dikarenakan Bawaslu merupakan salah satu lembaga yang juga menjadi sorotan terkait dengan kinerjanya, Bawaslu menjadi bagian yang penting dalam penyelenggaraan pemilihan umum. Bawaslu memperkuat lembaganya dengan berdasarkan pada aturan-aturan, adapun upaya memperkuat yang dimaksut adalah dengan menambah jumlah anggota Bawaslu hingga memperluas kewenangan Bawaslu.tentunya hal ini bukan tanpa alasan, Bawaslu mencoba memperkuat lembaganya karena berkaca dengan pemilihan umum tahun-tahun sebelumnya yang masih babyak kecurangan, sehingga dilakukannya perbaikan adalah guna meminimalisir kecurangan dan pelanggaran. Bawaslu dalam pemilihan umum keberadaannya sangat penting sehingga setiap Undang-Undang tentang pemilihan umum dirubah maka aturan terkait dengan Bawaslu juga akan berubah. 
Penyelenggara Pemilihan Umum atau Pemilu merupakan lembaga yang menjadi penyelenggara pemilu, penyelenggara pemilu terdiri dari Komisi Pemilihan Umum (KPU), Badan Pengawas Pemilu (Bawaslu), dan DKKP. Tentunya di dalam lembaga penyelenggara pemilu memiliki sebuah kesatuan fungsi yang diatur dalam Keputusan Penyelenggara Pemilu beserta surat edaran. Sesuai dengan teori Stufenbau yang mengibaratkan norma hukum bagaikan anak tangga, dimana lembaga yang menduduki bagian terendah harus mengikuti norma hukum yang berlaku pada lembaga yang menduduki bagian lebih tinggi atau tertinggi. Artinya adalah dalam penyelenggaraan pemilu, semua harus mengikuti pedoman yang digunakan yaitu Pancasila dan UUD 1945.

Sementara badan penyelenggara yang langsung berhadapan dan melayani pemilih dan peserta pemilu pada hari pemungutan dan penghitungan suara kurang mendapatkan perhatian.Badan penyelenggara yang dimaksud meliputi Panitia Pemilihan Kecamatan (PPK), Panitia Pemungutan Suara (PPS) dan Kelompok Penyelenggara Pemungutan Suara (KPPS) dengan status ad hoc. Seharusnya badan penyelenggara seperti PPK, KPPS, dan PPS juga harus diperhatikan kualitasnya karena bertanggung jawab pada kelangsungan pemungutan dan perhitungan suara. Untuk menghindari adanya kesalahan-kesalahan dalam pelaksanaan pemilu maka diperlukan adanya pelatihan-pelatihan untuk PPK, PPS, dan KPPS sehingga masing-masing memahami tugas, pokok, dan fungsinya(Susanto 2017).

Kelompok Penyelenggara Pemungutan Suara atau disingkat dengan KPPS merupakan salah satu penyelenggara Pemilu pada tingkat paling bawah dan dipilih oleh PPS atau Panitia Pemungutan Suara KPU Kabupaten/Kota.KPPS sendiri terdiri dari tujuh orang dan bertanggung jawab dalam pelaksanaan pemungutan dan perhitungan suara di Tempat Pemungutan Suara.KPPS menjadi bagian yang penting dikarenakan tugas KPPS adalah harus menjadi pelayan pemilih sehingga bisa memberikan hak pilihnya.Untuk melaksanakan tugas sebagai KPPS, anggota KPPS harus melaksanakan tanggung jawab dengan ketentuan-ketentuan seperti harus transparan, netral dan tidak memihak, serta harus menerapkan nilai-nilai demokrasi.Kenyataan yang ditemui di lapangan banyak sekali permasalahan yang berkaitan dengan KPPS, KPPS yang merupakan salah satu bagian paling ujung dari badan ad hoc dimaksud yang selalu dari pemilu ke pemilu mendapatkan 
sorotan. Sorotan berupa ketidakpuasan peserta pemilu akan kinerjanya. Tuduhan ketidakprofesional dan ketidaknetralan KPPS selalu diajukan ke proses pengaduan dan peradilan pemilu. Tanpa pernah memahami akan berbagai keterbatasan yang dihadapi mereka.

Keterbatasan mulai dari pemahaman akan regulasi, teknis pelaksanaan pemungutan suara dan penghitungan suara pada Ketua dan Anggota KPPS. Belum lagi kondisi daya tahan fisik KPPS yang telah bekerja sejak beberapa hari sebelum hari pemungutan dan penghitungan suara.Hasilnya adalah ketika terdapat kesalahan-kesalahan dalam pemilihan umum, Kelompok Penyelenggara Pemungutan (KPPS) menjadi sorotan karena KPPS dianggap sebagai penentu dari pemilu yang berkualitas. Di dalam penelitian Eduard Ola Bebe Gorantokan dengan judul Kualitas Kerja Kelompok Penyelenggara Pemungutan Suara pada Penyelenggaraan Pemilu Legislatif di Kabupaten Lembata Tahun 2014 yang menjelaskan bahwa ditemukan beberapa pelanggaran di dalam penyelenggaraan pemilu, kesalahan tersebut berasal dari ketidaksesuaian antara jumlah DPT dengan C-1 Plano, di dalam pemilu tersebut disinyalir terdapat penggelembungan suara. Adanya pelanggaran ini salah satunya disebabkan oleh anggota KPPS yang tidak sesuai dengan Undang-Undang No. 15 Tahun 2011 terkait dengan Penyelenggara Pemilihan Umum, salah seorang anggota KPPS pada TPS tersebut masih duduk di kelas dua bangku SMA, adanya hal ini tentunya menunjukkan bahwa belum memenuhi syaratnya anggota KPPS.

Beberapa kekurangan dari kualitas KPPS yang pernah diteliti oleh Eduard Ola Bebe Gorantokan dijelaskan bahwa umunya anggota KPPS kurang dalam pengetahuan, keterampilan, dan kemampuan.Tidak semua anggota KPPS yang mahir atau menguasai materi-materi dalam pemilu seperti lembar model C,C1 ataupun lampiran $\mathrm{C} 1$. Adanya hal yang demikian dikarenakan kurang maksimalnya Bimtek atau bimbingan teknis pra pemilu serta kurangnya panduan untuk KPPS dalam bentuk buku panduan. Sebagian anggota KPPS masih merasa kebingungan dalam pemecahan masalah yang terjadi karena kurangnya koordinasi (Ola 2017).

Di dalam penelitian Endang dan Nida (Endang 2017) yang berjudul Pola Rekrutmen Penyelenggara Pemilu Tingkat PPS dan KPPS untuk Pemilu yang Berintegritas dijelaskan terkait dengan faktor penyebab minimnya kualitas PPS dan KPPS dalam Pemilu. Faktor pertama adalah anggota PPS dan KPPS hanya 
merasa bekerja sementara sehingga hanya dianggap sebagai sampingan.Faktor kedua adalah minimnya pembinaan yang bersifat lanjutan dan secara menyeluruh untuk anggota PPS dan KPPS. Faktor ketiga adalah ketimpangan antara beban kerja yang dialami dengan honor yang diberikan. Faktor keempat adalah adanya ketergantungan PPS dan KPPS pada fasilitas pemerintah, dan faktor terakhir adalah tidak menjaminnya kualitas anggota PPS dan KPPS dalam proses rekrutmen, umunya proses rekrutmen hanya berdasarkan pada hubungan baik dengan elite-elite.

Permasalahan terkait dengan Kelompok Penyelenggara Pemungutan Suara lainnya pernah diteliti oleh Andrie Susanto dengan judul Disproporsionalitas Beban Tugas KPPS Studi Integritas Pemilu, di dalam penelitian tersebut dijelaskan banyak masalah yang dialami oleh KPPS.Adapun masalah tersebut berkaitan dengan beban-beban KPPS yang tentunya membawa pengaruh terhadap irregularitas, malapraktik, hingga berdampak pada kesehatan anggota KPPS.KPPS sebagai street-level bureaucracy mengalami berbagai kendala teknis dan dapat berpengaruh pada sikap mereka dalam mengambil keputusan.Tentunya adanya hal yang demikian berpengaruh pada pelayanan yang diberikan oleh KPPS. Seringkali KPPS mendapatkan banyak protes oleh masyarakat mulai dari antrian di TPS yang mungkin cukup panjang hingga kesalahan-kesalahan dalam perhitungan. Bahkan di dalam penelitian tersebut disebutkan terkait dengan masalah yang dialami oleh KPPS pada saat Pileg 2014 yaitu terkait dengan pembagian tugas yang tidak sesuai porsinya. Adanya masalah tersebut menyebabkan adanya irregularitas.Irregularitas adalah bentuk kesalahan yang dilakukan secara sengaja, misalnya adalah kecurangan. Tentunya, masalah irregularitas sangat menghambat proses pemungutan suara dan perhitungan suara. Secara otomatis hambatan pada proses pemungutan dan perhitungan suara akan memperlama kerja KPPS, dan dampak paling besar adalah mengganggu kesehatan KPPS. Terdapat beberapa anggota KPPS yang sakit hingga meregang nyawa akibat bebannya.Berdasarkan data yang diterima, terdapat sepuluh orang anggota KPPS yang meninggal dunia pada hari pencoblosan dan enam orang meninggal setelah pencoblosan.

Banyaknya permasalahan yang dialami oleh KPPS akan membawa masalah yang cukup panjang. Ketika masalah tersebut terjadi tentunya banyak yang akan 


\section{2 | The Journal of Society and Media 3(1)}

melihat betapa lemahnya manajemen dalam KPPS. Kemudian adanya masalah tersebut akan berimplikasi pada proses perhitungan suara yang dianggap kurang akurat. Setelah itu masyarakat akan kehilangan kepercayaan kepada hasil pemilu, hal ini dikarenakan tidak akuntabelnya penyelenggara pemilu.

Permasalahan yang dialami KPPS juga sangat berkaitan dengan sumber daya, hal ini dikarenakan pembuat kebijakan kurang memperhatikan sumber daya pada KPPS.Padahal KPPS merupakan street-level bureaucracy, artinya KPPS merupakan bagian yang berhadapan langsung dengan masyarakat, sehingga adanya persepsi masyakat terhadap kebijakan publik dipengaruhi oleh kinerja KPPS.Sebenarnya, KPPS dihadapkan dengan berbagai masalah seperti Sumber daya manusia, waktu kerja, informasi, bimbingan teknik, hingga terkait masalah pembagian tugas.Banyak sekali ditemukan beban ganda yang dialami oleh anggota KPPS, beban kerja ini dikarenakan banyak sekali tugas yang harus dikerjakan sedangkan waktu dan sumber daya yang diberikan tidak seimbang.Akibatnya adalah anggota KPPS seringkali melakukan kesalahan pada formulir C1. Beban yang sangat banyak ini akan menimbulkan tekanan pada anggota KPPS, tekanan akan berdampak pada kelelahan serta kurang fokus sehingga menimbulkan banyak kesalahan. Anggota KPPS diharuskan mengerjakan pekerjaan lebih berat dari

pekerjaan biasanya, hasilnya akan berdampak pada kesehatan. Selain itu, kesalahan yang dilakukan oleh KPPS akan menimbulkan terabaikannya hak-hak pemilih sehingga menimbulkan ketidaknyamanan pemilih dalam proses pemungutan suara, kemudian akan memberikan dampak menurunnya partisipasi pemilih dalam pemilu.

Pemilu 2019 sebagai pemilu serentak tentunya akan menambah tugas, tanggungjawab serta beban KPPS (Solihah 2016). Selain melayani pemilih di Tempat Pemungutan Suara (TPS) bersangkutan, Ketua dan Anggota KPPS akan melaksanakan administrasi pemungutan dan penghitungan perolehan suara untuk 5 surat suara dalam waktu satu hari. Proses administrasi kepemiluan di hulu yang demikian berat dan rumit akan mempengaruhi proses rekapitulasi perolehan suara di PPK dan tingkat selanjutnya.Di dalam Pemilu 2019 yang pertama kalinya dilaksanakan secara serentak mulai dari presiden dan wakil presiden, DPR RI, DPD, DPRD tingkat Provinsi, dan DPRD tingkat Kabupaten Kota. Banyaknya kertas suara yang diberikan kepada pemilih seringkali membuat pemilih merasa bingung selain itu tugas KPPS pun semakin berlipat, pemungutan dan perhitungan 
suara akan memakan banyak waktu, belum lagi ketika terdapat kesalahan yang akan berbuntut panjang. Di dalam penelitian Ratna yang berjudul Peluang dan Tantangan Pemilu Serentak 2019 dalam Perspektif Politik dijelaskan bagaimana tantangan yang dihadapi untuk mewujudkan adnaya pemilu serentak (Solihah 2016). Tantangan tersebut dihadapi tidak hanya oleh partai politil ataupun kandidat melainkan juga oleh pemerintah, pemilih, dan penyelenggara pemilu.Melalui kacamata politik, tentunya untuk menghadapi pemilu serentak diperlukan usaha-usaha, misalnya perlunya dilakukan reformasi sistem perwakilan, pemilihan, hingga kepertaian untuk melaksanakan pemilu serentak 2019 supaya lebih efektif.

\section{METODE PENELITIAN}

Dalam kerangka kajian kualitatif kebijakan, penelitian ini akan menganalisa regulasi di UU Nomor 7 Tahun 2017 mengenai Pemillihan Umum dan regulasi yang terkait. Dari hasil analisis terhadap data sekunder dilakukan verifikasi dan konfirmasi di antara kebijakan, komponen-komponen proses dan pelaksanaan tugas KPPS (Mayer dan Greenwood, 1984, 455).Setelah itu didapatkan kesimpulan.

Penelitian ini menggunakan teori Fenomenologi Edmund Husserl. Fenomenologi merupakansuatu pendekatan ilmiah yang mempunyai tujuan untuk mengkaji fenomena tanpa adanya proses interpretasi dan abstraksi yang dialami secara langsung. Pandangan fenomenologi ini dipengaruhi oleh tiga tokoh yaitu Edmund Husserl, Alfred Schultz, dan Weber.

Edmund Husserl merupakan seorang filsuf yang dikenal sebagai tokoh penting dalam fenomenologi.Bagi Edmund Husserl Fenomenologi adalah kajian filosofis yang menggambarkan semua bidang pengalaman manusia yang dialami dalam sebuah kesadaran. Menurutnya, fenomenologi ialah suatu kajian yang tidak pernah ada akhirnya, sehingga ia menyebut fenomenologi sebagai pemula yang abadi. Husserl menjadikan filsafat fenomenologi sebagai pondasi struktur pengalaman manusia dalam mengorganisasikan realitas sehingga dapat menjadi terintegrasi dan autentik. 


\section{4 | The Journal of Society and Media 3(1)}

Landasan pokok fenomenologi ialah manusia yang menafsirkan pengalamannya dengan memberi makna pada fenomena yang dialaminya.Fenomenologi merupakan realitas yang lahir dari sudut pandang actor social yang mengalami suatu fenomena dalam kehidupannya.Pemahaman mengenai fenomenologi dicapai dalam tataran personal yang terkonstruksi secara subjektif.

Husserl meyakini fenomena hanya dapat dicermatioleh orang yang mengalami fenomena itu sendiri. Menurutnya, seseorang yang ingin mengetahui sebuah fenomena harus melihatkembali fenomena tersebut dengan apa adanya (Look at the thing it self). Oleh sebab itu, peneliti tidak diperbolehkan untuk menyertakan asumsi teoritis didalam studinya, peneliti harus menyimpan sementara hasil pemikiran, dan pengetahuan yang diyakininya mengenai suatu fenomena dan harus mendefinisikan ide-ide yang berasal dari anggota masyarakat.Hanya dengan begitu peneliti dapat mencapai sebuah pemahaman yang sejujurnya tentang fenomena.

Fenomenologi ialah teori sosiologi yang memiliki pengaruh yang luas, dalam sosiologi kontemporer maupun dalam sosiologi postmodern.Pendekatan fenomenologi merupakan metode yang diterapkan didalam kajian sosiologi agar dapat memahami suatu fenomena sosial.Fenomenologi Husserl tentunya berbeda dengan fenomena menurut Kant, jika Kant berasumsi bahwa subyek mengenal fenomena saja bukan noumena, tetapi menurut Husserl noumena sendiri menjadi cakupan dari fenomena.Fenomena dapat dihasilkan dari adanya kesadaran manusia dalam melakukan sebuah kegiatan.Adanya fenomenologi berarti peneliti bisa mempelajari pengalaman - pengalaman dari orang yang pernah mengalaminya secara langsung dan menjadikan kita seolah - olah juga mengalami hal tersebut.Fenomenologi tidak hanya memberikan klasifikasi dari tindakan yang dilakukan oleh manusia secara sadar, tetapi juga memberikan sebuah presikdi terhadap tindakan yang waktu mendatang dengan melihat berbagai aspek terkait hal tersebut.Sumber dari hal-hal tersebut adalah pemaknaan objek terhadap pengalaman yang dialaminya.

Terdapat beberapa langkah dalam metode fenomenologi atau "langkah langkah metodis reduksi”, adanya reduksi tersebut berarti menunda upaya dalam memberikan kesimpulan pada setiap prasangka terhadap sesuatu realitas tertentu.Langkah metodis reduksi tersebut berarti menempatkan adanya fenomena 
dalam tanda kurung. Beberapa metodenya antara laun adalah "reduksi eidetic, reduksi fenomenologi, dan reduksi transedental:, dengan adanya upaya penempatan sebuah fenomena dalam tanda kurung memberikan arti bahwa peneliti memberikan tempat terhadap perhatian dalam struktur pengalaman yang sadar dengan kata kunci apakah kesadaran tersebut bagian dari kesengajaan atau kesadaran tersebut tercipta karena langsung terhubung dengan suatu hal. Misalnya kesadaran terhadap sebuah batang pohom, jika peneliti memberikan tempat pohon dalam tanda kurung artinya perhatian peneliti bukan lagi pada fisik pohon melainkan makna dari pohon tersebut yang ada pada pengalaman peneliti.

Husserl memberikan asumsi terkait dengan "noema dan noematic" dari sebuah pengalaman.Dengan adanya reduksi transedental ditemukan terkait dengan intensionalitas atau yang disebut dengan esensi kesadaran.Hal yang penting dari reduksi ini adalah bagaimana intepretasi subyek terhadap objek selanjutnya. Husserl memberikan 4 rumusan dalam aktivitas inheren pada kesadaran, antara lain adalah "objektivikasi, identifikasi, korelasi, dan konstitusi". Dengan hal tersebut akan ditemukan terkait penghayatan terhadap dunia.

Subjek transedental akan mengkonstitusikan dunianya sendiri dengan keunikan dan kekhasan dari perspektinya sendiri. Dunia dipahami oleh subyek secara pribadi bukan sebagai dunia objektif secara fisik dan material.Fenomenologi Husserl bercorak idealistik dimana sumber dari datanya adalah pada diri dan kesadaran subjek. Beberapa pokok fenomenologi Husserl antara lain adalah sebagai berikut :“fenomena merupakan sebuah realitas sendiri yang tampak, tidak ditemukan batas antara subjek dengan sebuah realitas, kesadaran bersifat sebagai sesuatu yang intensional, dan terdapat interaksi dari tindakan kesadaran dengan objek yang disadari”.

\section{HASIL DAN PEMBAHASAN}

Pelaksanaan pemilu 2019 mendatang merupakan pemilu serentak nasional pertama kali dalam sejarah kepemiluan Indonesia. Untuk pertama kalinya, pemilu legislatif (calon anggota DPR, DPD, DPRD Provinsi dan DPRD Kabupaten/Kota) dilangsungkan pada hari yang sama dengan pemilihan umum Presiden dan Wakil Presiden (Pilpres) yakni pada tanggal 17 April 2019. 
Dari sisi keserentakan, pemilu 2019 bukanlah yang pertama dilaksanakn di Indonesia.Pemilihan umum kepala daerah dan wakil kepala daerah (Pilkada) secara serentak telah mendahului sebelumnya. Gelombang pertama di 9 Desember 2015, gelombang kedua pada 15 Februari 2017 dan 27 Juni 2018 sebagai gelombang ketiga (Pandiangan 2018).

Sementara dari konteks perjalanan pemilu di tingkat nasional, pemilu 2019 merupakan pemilu ke 12 setelah pemilu 1955 (memilih DPR dan Badan Konstituante pada waktu berbeda), 1971, 1977, 1982, 1987, 1992, 1997, 1999, 2004, 2009, 2014. Pemilu 1971 hingga 1999 memilih lembaga legislatif).Lalu pemilu 2004 hingga 2014, memilih lembaga legislatif dan Presiden/Wakil Presiden pada waktu berbeda.

Khusus untuk pemilu sejak periode reformasi, secara substansi dan teknis regulasi, pelaksanaan dan peserta Pileg dan Pilpres mengalami perubahan signifikan seperti pada Tabel1.

Tabel 1

Regulasi, Pelaksanaan dan Peserta

Pemilihan Umum Legislatif dan Pemilihan Umum Presiden dan Wakil Presiden 1999-2019

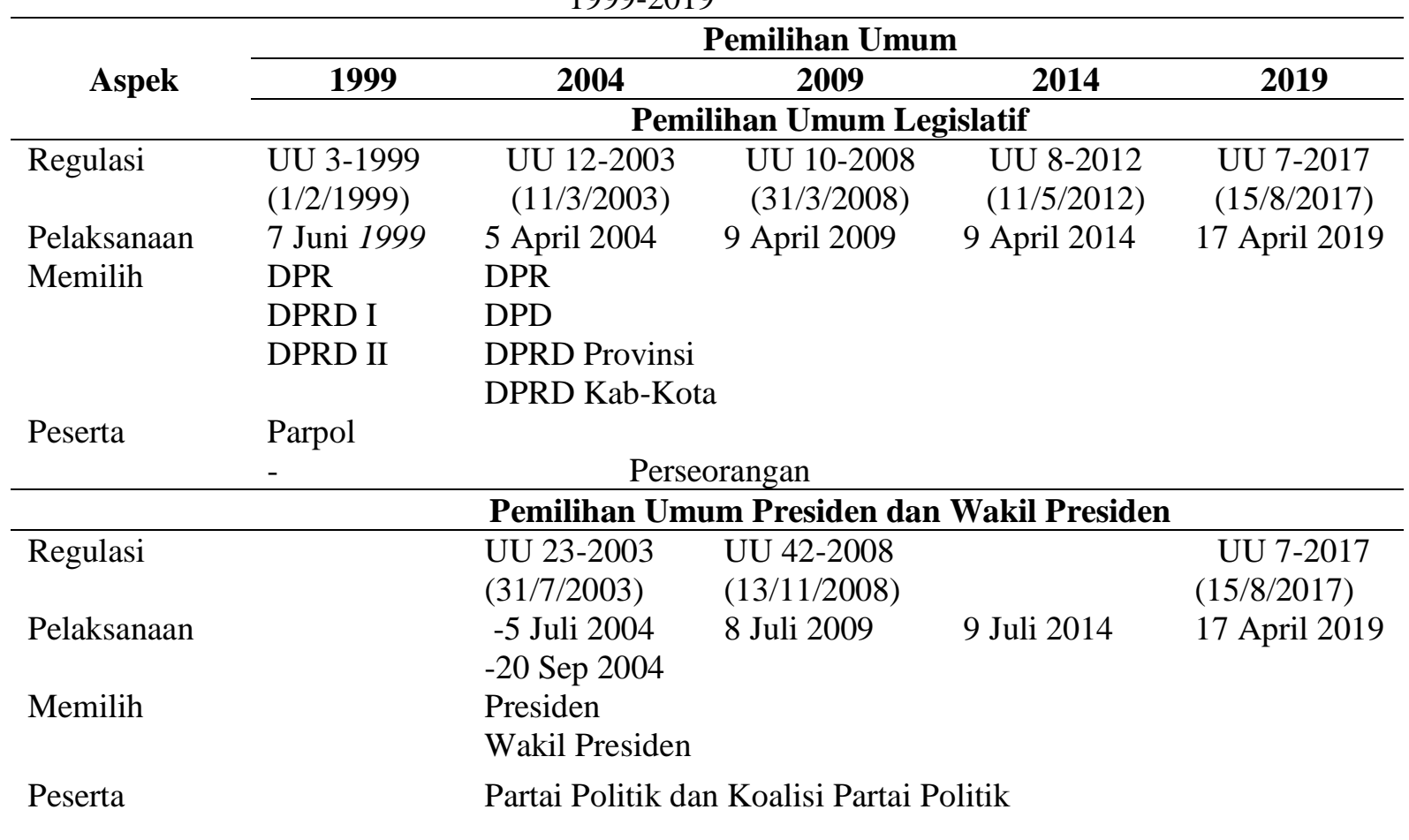

Sumber: Andreas Pandiangan, Pengantar Ilmu Politik: Suatu Pengantar, (Semarang: UNIKA Soegijapranata, 2017), h. 115(Pandiangan 2017)

Sebagai sebuah kegiatan kenegaraan dan politik, pemilu diselenggarakan oleh suatu badan penyelenggara (electoral management body-EMB.Sejak Pemilu 
1955, badan penyelenggara pemilu di Indonesia silih berganti diisi personil dari berbagai pihak yang berkepentingan terhadap pemilu. Latar belakang pembentukan dan posisi lembaga penyelenggara pemilu akan pemerintah dan pihak lainnya menentukan model badan penyelenggara pemilu.

Indonesia telah pernah membentuk badan penyelenggara pemilu dari 3 model yakni model independen (Independent Model), model pemerintah (Governmental Model) dan model campuran antara model independen dan model pemerintah (Mixed Model)(IDEA 2006). Model independen sejak Pemilu 2004 hingga sekarang.Model campuran di Pemilu 1955 dan 1999.Serta model pemerintah selama pelaksanaan pemilu di bawah rejim Orba.

Pilihan model badan penyelenggara sangat ditentukan pihak mana yang diatur di undang-undang sebagai penyelenggara pemilu (periksa Tabel 2).Pemilu 1955 diselenggara Pemerintah dengan sistem parlementer sehingga model badan penyelenggaranya model campuran. Selain unsur pemerintah, di badan penyelenggara terdapat juga unsur-unsur partai-partai politik yang memiliki perwakilan di DPR(Anon n.d.).

Hal yang berbeda selama rejim Orba, meskipun diamanatkan Pemerintah di bawah pimpinan Presiden(Anon n.d.)sebagai pelaksana pemilu namun model badan penyelenggara pemilu tidak seperti di Pemilu 1955. Model pemerintah menjadi pilihan model badan penyelenggara sejak Pemilu 1971 hingga 1997. Selama 6 kali pemilu Orde Baru (Orba)(Anon n.d.)pemilu dilaksanakan Pemerintah dibawah pimpinan Presiden. Dalam melaksanakan pemilu, Presiden membentuk Lembaga Pemilihan Umum (LPU).Di dalam LPU terdapat Panitia Pemilihan Indonesia (PPI) serta jajarannya hingga ke tingkat desa/kelurahan.

Pemilu pertama di reformasi, Pemilu 1999, menjadikan Presiden sebagai penanggungjawab pemilu.Komisi Pemilihan Umum (KPU) merupakan penyelenggara pemilu yang anggotanya terdiri dari partai-partai politik peserta pemilu dan pemerintah (Anon n.d.). Meskipun sistem pemerintahan presidensial namun demi menjaga kestabilan politik serta demi tujuan legitimasi hasil pemilu maka model badan penyelenggara pemilu mengambil model campuran. Suatu yang patuh dipertanyakan karena salah satu bagian badan penyelenggara yakni dari unsur partai politik juga merangkap sebagai pihak yang bersaing dalam 
pemilu. Sejak Pemilu 2004(Anon n.d.) hingga sekarang, pemilu yang diadakan oleh KPUyang bersifat nasional, mandiri, dan pasti (Anon n.d.).

Tabel 2

Struktur Badan Penyelenggara

Pemilihan Umum 1955-2019

\begin{tabular}{|c|c|c|c|c|c|}
\hline \multicolumn{6}{|c|}{ Pemilihan Umum } \\
\hline Kedudukan & 1955 & 1971,1977 & $\begin{array}{l}1982,1987, \\
1992,1997\end{array}$ & 1999 & $\begin{array}{l}2004,2009, \\
2014,2019\end{array}$ \\
\hline Ibukota Negara & \multicolumn{3}{|c|}{ Panitia Pemilihan Indonesia (PPI) } & $\begin{array}{l}\text {-KPU } \\
\text {-PPI }\end{array}$ & KPU \\
\hline Daerah & \multicolumn{5}{|l|}{ Panitia } \\
\hline Pemilihan & Pemilihan & \multirow{2}{*}{\multicolumn{3}{|c|}{ Panitia Pemilihan Daerah (PPD) Tingkat I }} & \\
\hline Ibukota Provinsi & & & & & KPU Provinsi \\
\hline Ibukota Daerah & Panitia & \multicolumn{3}{|c|}{ Panitia Pemilihan Daerah (PPD) Tingkat II } & KPU \\
\hline Tingkat II & $\begin{array}{l}\text { Pemilihan } \\
\text { Kabupaten }\end{array}$ & & & & Kabupaten/Kota \\
\hline Ibukota & \multicolumn{3}{|c|}{ Panitia Pemungutan Suara } & Panitia & Pemilihan \\
\hline Kecamatan & & & & \multicolumn{2}{|c|}{ Kecamatan (PPK) } \\
\hline \multirow[t]{2}{*}{ Desa/Kelurahan } & \multicolumn{3}{|c|}{ Panitia Pendaftaran Pemilih } & \multicolumn{2}{|c|}{$\begin{array}{l}\text { Panitia Pemungutan Suara } \\
\text { (PPS) }\end{array}$} \\
\hline & & & & KPPs & \\
\hline
\end{tabular}

Sumber: diolah dari berbagai perundang-undangan kepemiluan

Kegiatan pemungutan suara dan penghitungan suara sejak pemilu 1955 hingga pemilu 2019 mendatang, selalu diatur dilaksanakan pada hari yang sama. Bila di pemilu 1955 dan 2 pemilu awal Orde Baru (Orba), 1971 dan 1977, penyelenggara kegiatan pemungutan dan penghitungan suara dilaksanakan badan yang dikenal Panitia Pemungutan Suara (PPS) yang bertempat di desa/kelurahan.

Di Pemilu 1971 dan 1977, PPS mempunyai tugas untuk membantu PPD II dan melangsungkan pengambilan suara.anggota PPS dilantik dan diberhentikan oleh Bupati/Walikota/Kepala Daerah Tingkat II atas usul Camat. PPS menetapkan jumlah dan tempat pemungutan suara bagi setiap daerah sehingga pemungutan suara dapat dijalankan dengan mudah dan lancar.Pemungutan suara untuk 3 jenis badan perwakilan (DPR, DPRD I dan DPRD II) dilangsungkan secara bersamasama.Setelah berakhir pemungutan suara segera diadakan perhitungan suara ditempat yang telah ditentukan.Pada Pemilu 1982, melalui Peraturan Pemerintah Nomor 41 Tahun 1980 (Anon n.d.) diatur bahwa jajaran terendah badan penyelenggara pemilu yakni KPPS. KPPS dengan jumlah sebanyak 7 orang melaksanakan pemungutan dan penghitungan suara untuk 3 badan legislatif.Tugas dan cakupan tanggungjawab tersebut tetap hingga Pemilu 1999.Saat Pemilu 1999, dengan perpaduan unsur partai politik dan pemerintaha, struktur keanggotaan 
KPPS dimulai dari Ketua, Wakil Ketua dan Anggota KPPS.Serta dilengkapi dengan 2 orang anggota Pertahanan Sipil (Hansip) sebagai petugas keamanan.

Sejak Pemilu 2004, KPPS dengan tetap beranggotakan 7 orang menyelenggarakan pemilu legislatif untuk 4 badan legislatif (DPR, DPD, DPRD Provinsi dan DPRD Kabupaten/Kota) pada hari yang sama untuk pemungutan dan penghitungan suara. Sementara untuk Pilpres dilakukan pada waktu yang berbeda.

Khusus untuk kegiatan pemungutan suara 4 badan legislatif, tidak terlalu masalah bagi Ketua dan Anggota KPPS. Namun begitu memasuki proses penghitungan suara, tugas mulai dirasakan melelahkan karena cara penghitungan dalam sistem proporsional terbuka berbeda dengan sistem proporsional tertutup. Dimungkinkan pemilih mencoblos/mencongtreng sekaligus di partai politik dan calon legislatif.Bila tidak cermat maka anggota KPPS menghitungnya pilihan dari 1 pemilih menjadi ganda.

Babak kelelahan Ketua dan Anggota KPPS masih berlanjut pada proses mengadministrasian hasil penghitungan suara ke dokumen berbagai dokumen. Mulai dari dokumen hasil dari pemungutan dan penghitungan suara setelahnya membuat sertifikat penghitungan suara yang wajibdiserahkan kepada saksi pemilu, Pengawas TPS, dan PPK melalui PPS.Sehingga dalam prakteknya, penyelenggaraan pemungutan dan penghitungan suara serta penyelesaiaan administrasinya yang direncanakan selesai dalam 1 hari menjadi lebih menjelang dini hari berikutnya.

Kondisi tersebut telah dialami anggota KPPS sebanyak 5.217.109 orang di Pemilu 2004(Umum 2004), 3.633 .329 orang di Pemilu 2009 (Umum 2009), 3.350.795 orang di Pemilu 2014 dan akan dialami sebanyak 5.706.225 orang di Pemilu 2019 (Anon n.d.).

Beban tugas, wewenang dan kewajiban KPPS diatur secara rinci melalui undang-undang tentang Penyelenggara Pemilihan Umum (Anon n.d.). Tugas, wewenang, dan kewajiban KPPS yaitu diantaranya:

1. Mmberikan pengumuman daftar pemilih tetap di TPS;

2. Memberikan daftar pemilih tetap kepada saksi Pemilu yang hadir dan Pengawas Pemilu yang berada di Lapangan; 
3. Melangsungkan pemungutan dan penghitungan suara di TPS yang telah ditentukan;

4. Menunjukkan hasil penghitungan suara di TPS;

5. Menindaklanjuti temuan dan laporan yang disampaikan oleh saksi, Pengawas Pemilu Lapangan,peserta Pemilu, dan masyarakat pada hari pemungutan suara dengan segera;

6. Bertanggung jawab untuk menjaga dan mengamankan keutuhan kotak suara setelah kotak suara disegel;

7. Membuat sertifikat penghitungan suara dan wajib diserahkan kepada saksi Pemilu,Pengawas Pemilu Lapangan, dan PPK melalui PPS;

8. Memberikan hasil penghitungan suara kepada PPS dan Pengawas Pemilu Lapangan;

9. Memberikan kotak suara yang sudah tersegel berisi surat suara serta sertifikat hasil penghitungan suara kepada PPK melalui PPS dengan segera pada hari yang sama;

10. Melaksanakan tugas, wewenang, dan kewajiban lain yang diberikan oleh KPU, KPU Provinsi, KPU Kabupaten/Kota, PPK, dan PPS sesuai dengan peraturan perundangundangan; dan

11. Melaksanakan tugas, wewenang, dan kewajiban lain sesuai ketentuan dengan ketentuan peraturan perundangundangan.

Bila dibandingkan dengan pengaturan sebelumnya, Undang-Undang Nomor 22 Tahun 2007 Mengenai Penyelenggara Pemilihan Umum, merupakan pengaturan tertinggi penyelenggara pemilu, pengaturan KPPS di UU Nomor 7 Tahun 2017 lebih rinci. Cakupan rincian yang dimaksud yakni tugas, wewenang dan kewajiban KKPS. Pasal 60 UU Nomor 7 Tahun 2017 mengatur 7 tugas KPPS yakni:

1. Mengumumkan DPT di TPS;

2. Menyerahkan DPT kepada saksi pemilu yang hadir dan Pengawas TPS dan apabila peserta pemilu tidak memiliki saksi DPT dapat diserahkan kepada peserta pemilu;

3. Melangsungkan pemungutan dan penghitungan suara di TPS yang telah ditentukan; 
Pandiangan:KELOMPOKPENYELENGGARA

PEMUNGUTAN SUARA (KPPS) PEMILU

2019: TANGGUNG JAWABDAN BEBAN

KER J A

4. Mengadakan berita acara seputar pemungutan dan penghitungan suara serta membuat sertifikat penghitungan suara dan wajib diserahkan kepada saksi pemilu, Pengawas TPS, dan PPK melalui PPS;

5. Menjalankan tugas lain yang diberikan oleh KPU, KPU Provinsi, KPU Kabupaten/Kota, PPK, dan PPS yang sesuai dengan peraturan perundangundangan yang telah dibuat;

6. Memberikan surat pemberitahuan kepada pemilih sesuai dengan DPT untuk menggunakan hak pilihnya di TPS; dan

7. Menjalankan tugas lain sesuai dengan ketentuan peraturan perundangundangan yang tercantum.

Lalu Pasal 61 mengatur 3 wewenang, yakni:

1. Memberikan pengumuman hasil penghitungan suara di TPS;

2. Mempunyai wewenang lain yang diberikan oleh KPU, KPU Provinsi, KPU Kabupaten/Kota, PPK, dan PPS sesuai dengan peraturan perundangundangan; dan

3. Menjalankan wewenang lain sesuai dengan ketentuan peraturan perundangundangan

Sementara Pasal 62 mengatur 7 kewajiban, yakni:

1. Menempelkan DPT di TPS;

2. Menindaklajuti temuan dan laporan yang disampaikan oleh saksi, Pengawas TPS, Panwaslu Kelurahan/Desa, peserta pemilu, dan masyarakat pada hari pemungutan suara dengan secepatnya;

3. Bertanggung jawab untuk menjaga dan mengamakan keutuhan kotak suara setelah penghitungan suara dan setelah kotak suara tersegel;

4. Memberikan hasil penghitungan suara kepada PPS dan Panwaslu Kelurahan/Desa;

5. Memberikan kotak suara disegel yang berisi surat suara dan sertifikat hasil penghitungan suara kepada PPK melalui PPS secepatnya pada hari yang sama;

6. Melaksanakan kewajiban lain yang diberikan oleh KPU, KPU Provinsi, KPU Kabupaten/Kota, PPK, dan PPS sesuai dengan peraturan perundangundangan; dan 
7. Menjalankan kewajiban lain sesuai dengan ketentuan peraturan perundangundangan.

KPPS merupakan struktur terendah dari Komisi Pemilihan Umum (KPU) (Anon n.d.)sebagai penyelenggara pemilu cenderung diabaikan saat ada perubahan kebijakan politik kepemiluan dan perubahan organisasi badan penyelenggara pemilu. Meskipun tugas, wewenang dan kewajiban KPPS mengalami perubahan ke arah yang lebih luas dan berat di Pemilu 2019, namun kebijakan politik kepemiluan masih tetap dibandingkan dengan di pemilu sebelumnya.Bahkan organisasi KPPS tetap dikelola 7 orang sementara beban tugasnya bertambah.

Lain hal nya ketika disadari perlu penguatan penegakan kode etik penyelenggara pemilu.Awalnya ditangani KPU dan KPU Provinsi, lalu melahirkan kebijakan untuk membentuk badan penyelenggara baru di bidang penegakan kode etik.Diikuti pembentukan Dewan Kehormatan Penyelenggara Pemilu (DKPP) di tahun 2011.DKPP sebagai lembaga yang bertugas menangani pelanggaran kode etik Penyelenggara Pemilu dan merupakan satu kesatuan fungsi penyelenggaraan Pemilu.

Hal yang sama terjadi pada pemekaran jumlah personil anggota KPU Provinsi dan anggota Bawaslu Provinsi serta penetapan Bawaslu di Kabupaten/Kota sebagai badan penyelenggara tetap, bukan lagi berstatus ad hoc.

Pemberian tugas, wewenang dan kewajiban KKPS yang demikian berat pada Pemilu 2019 tanpa diiringi dengan reorganisasi jumlah dan masa bakti anggota KPPS serta perhatian pada fasilitas (bimbingan teknis, biaya operasional) dan kesejahteraan (honor) berpotensi menurunkan kinerja optimal KPPS. Di sisi lain adanya tekanan dari badan penyelenggara di atasnya dan peserta pemilu.

\section{KESIMPULAN}

KPPS merupakan ujung tombak pelaksanaan pemungutan dan penghitungan suara di Pemilu 2019.Termasuk melayani hak pilih masyarakat. Hasil kerja KPPS akan sangat menentukan kualitas Pemilu 2019 dan berpeluang akan digugat masyarakat dan peserta Pemilu 2019 bila penyelenggaraan pemilu tidak memenuhi prinsip-prinsip: mandiri, jujur, adil, berkepastian hukum, tertib, terbuka, proporsional, profesional, akuntabel, efektif dan efisien. 


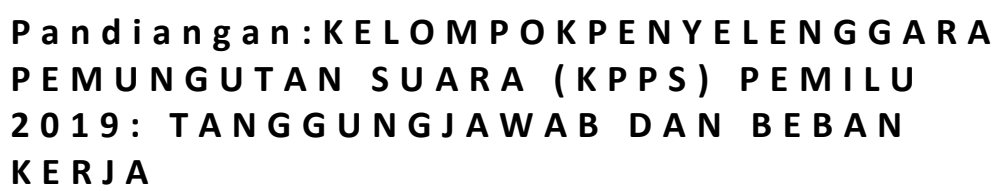

Tugas, wewenang dan kewajiban KKPS yang demikian luas dan berat di Pemilu 2019 kiranya diimbangi dengan perubahan organisasi dan fasilitas serta kesejahteraan yang diterima oleh Ketua dan Anggota KPPS.

\section{REFERENSI}

Anon. n.d. Pasal 15 Undang-Undang Nomor 12 Tahun 2003 Tentang Pemilihan Umum Anggota Dewan Perwakilan Rakyat, Dewan Perwakilan Daerah, Dan Dewan Perwakilan Rakyat Daerah.

Anon. n.d. Peraturan Komisi Pemilihan Umum Nomor 3 Tahun 2018 Mengenai Pembentukan Dan Tata Kerja Panitia Pemilihan Kecamatan, Panitia Pemungutan Suara, Dan Penyelenggara Pemungutan Suara Dalam Penyelenggaraan Pemilihan Umum.

Anon. n.d. Peraturan Pemerintah Nomor 41 Tahun 1980 Mengenai Pelaksanaan Undang-Undang Pemililhan Umum.

Anon. n.d. Sesuai Dengan Amanat Pasal 22 E Ayat (5) Undang-Undang Dasar Negara Republik Indonesia Tahun 1945.

Anon. n.d. Setelah KPU, KPU Provinsi, KPU Kabupaten/Kota, Panitia Pemilihan Kecamatan (PPK) Dan Panitia Pemungutan Suara (PPS). Periksa Pasal 6 UU Nomor 7 Tahun 2017 Tentang Pemilihan Umum.

Anon. n.d. Undang-Undang Nomor 15 Tahun 1969 Mengenai Pemilihan Umum Anggota-Anggota Badan Permusyawaratan/Perwakilan Rakyat.

Anon. n.d. Undang-Undang Nomor 15 Tahun 2011 Mengenai Penyelenggara Pemilihan Umum.

Anon. n.d. Undang-Undang Nomor 7 Tahun 1953 Mengenai Anggota Konstituante Dan Anggota Dewan Perwakilan Rakyat.

Endang, Sulastari. 2017. "Pola Rekrutmen Penyelenggara Pemilu Tingkat PPS Dan KPPS Untuk Pemilu Yang Berintegritas.” Jurnal Ilmu-Ilmu Sosial 3(1):73-88.

Fauzi, Agus Machfud. 2018. " Voters Participation Target Vs Democracy Election organizer program on the use of voting rights in East Java 2018." Proceedings of the 1st International Conference on Social Sciences (ICSS 2018). 3(1): 311-315.

Fauzi, Agus Machfud. 2018. "Pengembangan Integrasi Sidalih Antara Pilwali Surabaya Dan Pilgub Jawa Timur: Optimalisasi Pelayanan Publik Kpu Kota Surabaya." JPSI (Journal of Public Sector Innovations). 3(1): 1-5.

Hamimah, Siti. 2018. "Memperkuat Peran Dan Fungsi Bawaslu Dalam Pengawasan Dan Penegakan Hukum Pemilu." Seminar Nasional Hukum Universitas Negeri Semarang 4(3):803-28. 
Handitya, Binov. 2018. "No Title.” Seminar Nasional Hukum Universitas Negeri Semarang 4(2):384-365.

Haryanti, Dewi. 2015. "Konstruksi Hukum Lembaga Penyelenggara Pemilihan Umum Di Indonesia Ditinjau Dari Teori S Tufenbau." Jurnal Pembaharuan Hukum 2(2):270-78.

IDEA, International. 2006. Electoral Management Design-An Overview of the International IDEA Handkbook. Stockholm Sweden: International IDEA.

Ola, Eduard. 2017. “Kualitas Kerja Kelompok Penyelenggara Pemungutan Suara Pada Penyelenggaraan Pemilu Legislatif Di Kabupaten Lembata Tahun 2014.” Jurnal Imu Politik.

Pandiangan, Andreas. 2017. Pengantar Ilmu Politik: Suatu Pengantar. Semarang: UNIKA Soegijapranata.

Pandiangan, Andreas. 2018. “Akurasi Daftar Pemilih Pilgub 2018 Dan Kestabilan Pilkada, Makalah Pada Seminar Nasional Tahun 2018 'Pemerataan Pembangunan Untuk Pertumbuhan Berkualitas' Yang Diselenggarakan Bappeda Provinsi Jawa Tengah.”

Pratama, Maslekah. 2016. "Peran Komisi Pemilihan Umum Dalam Sosialisasi Pemilu Sebagai Upaya Untuk Meningkatkan Partisipasi Politik Masyarakat Pada Pemilu Presiden 2014 Di Kalimantan Timur." Jurnal Ilmu Komunikasi 4(1):30-43.

Ramlan Surbakti, Kris Nugroho. 2015. Studi Tentang Desain Kelembagaan Pemilu Yang Efektif. Jakarta: Kemitraan.

Solihah, Ratnia. 2016. "Peluang Dan Tantangan Pemilu Serentak 2019 Dalam Perspektif Politik." Jurnal Ilmiah Ilmu Pemerintahan 3(1).

Susanto, Andrie. 2017. "Disproporsionalitas Beban Tugas KPPS Studi Integritas Pemilu." Jurnal Politik Indonesia 2(1):9-19.

Umum, Komisi Pemilihan. 2004. Pemilihan Umum 2004 Dalam Angka Dan Gambar Peristiwa. Jakarta: Komisi Pemilihan Umum.

Umum, Komisi Pemilihan. 2009. Pemilihan Umum 2009 Dalam Angka Dan Gambar Peristiwa. Jakarta: Komisi Pemilihan Umum. 